\title{
Three-Dimensional Culture of Hybridoma Cells Secreting Anti-Human Chorionic Gonadotropin by a New Rolling Culture System
}

\author{
Yan Wang, Hong-Li Jiao, Jin-Zhu Zhang, and Rong-Qiao He \\ Lab of Visual Information Processing, Centre for Brain and Cognitive Sciences, Institute of Biophysics, \\ Chinese Academy of Sciences, Chaoyang District, Beijing 100101, China
}

Received 21 May 2003; accepted 5 September 2003

\begin{abstract}
Cell growth rate and production of monoclonal antibody (MAb) of hybridoma cells producing anti-human chorionic gonadotropin (hCG) MAb have been used as investigation criteria in double-mouthed rolling bottle (DMRB). Compared with T- ask cell culture, both of the cell number and MAb production increased by approximately $42.5 \%$ when the medium was supplemented with $5 \%$ fetal calf serum (FCS) and DMRB rotated at 2 turns per minute. Yield of MAb was experimentally related to the number of viable cells. Interestingly, MAb yield was four times as high as that cultured in T-ask in the rst 24 hours, and about $75 \%$ yield of total MAb was secreted by 48 hours during the culture. It appears that the promoted cell growth and MAb yield are resulted from the three-dimensional growth of hybridoma cells under a suitably revolving condition.
\end{abstract}

\section{INTRODUCTION}

Since the hybridoma technology was established for preparation and production of monoclonal antibody (MAb) in 1975 [1], a large variety and quantity of antibodies have been produced and widely used in biological researches, medical diagnoses, and therapies. The production of MAb from ascites by culturing hybridomas in the peritoneum of a living mouse makes a high yield of antibody; however, it is not only restricted by animal protection laws, but also involved in some problems of the antibody purity and practicability in human therapies. Many efforts have been made to improve the production of MAb at high titer in consideration of the economical effectivity. Aside from conventional T- ask culture, a variety of methods of hybridoma cell culture in vitro have been developed, such as roller bottles (or spinner asks, one-mouthed), hollow bre bioreactors, dialysis tubing, and macroporous microcarrier beads $[2,3,4,5,6]$. The process to raise MAb with both high yield and quality is still highly interesting, and processing of the resultant hybridoma cell culture in vitro needs further investigating and improving [7].

Rotated cell culture system (RCCS) by simulating microgravity was developed on the basis of clinostat equipment (US patent) [8]. The clinostat has been employed to produce a vector-average gravitational environment. It was rst used by plant physiologists more than 100 years ago to study gravitational biological effects on plants [9]. Recently, it has been used to study mammalian cell growth, differentiation, and morphogenesis in response to alterations in gravitational conditions $[10,11,12,13]$. It was strongly recommended that clinostat experiments should rst be investigated before a biology object was proposed for a space- ight experiment [ 14]. In this cultural system, when the radius and the revolution speed of a rotating bottle are on a certain scale, the centrifuge force is therefore closely equal to the gravity on cells. Under this condition, it allows the cells to grow in three dimensions, which could be, in some sense, simulated to the parent tissue condition in vivo, such as some cultures for liver cells and cartilage cells. Applying RCCS, various cell lines were successfully cultured, including breast and prostate cancer cells that were difficult to culture under the conventional culture conditions [15].

A new type of DMRB (double-mouthed rolling bottle), derived from conventional rotated bottle, has been designed (Chinese patent) [16]. It is operated conveniently with a better gas-exchanging efficiency and a lower cost. Furthermore, a large scale of MAb can be produced by laying more DMRBs on the rollers of the rolling cell culture system (Chinese patent) [17]. In this paper, hybridoma cell growth and MAb productivity cultured in DMRBs and T- asks are presented.

\section{MATERIALS AND METHODS}

Reagents and cell culture apparatus. DMEM cell culture medium with a low glucose concentration, fetal calf serum (FCS), and trypsin were from Sigma Chem Co (St Louis, Mo, USA). Microcarriers beads (Cytodex 3) were 


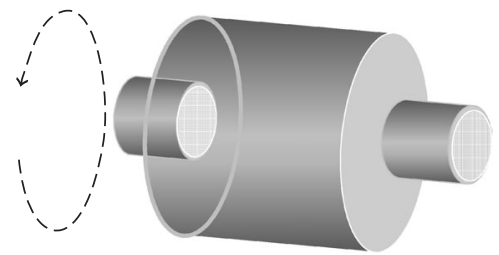

FIgURE 1. Diagram of a DMRB for culture of hybridoma cells. The cured surface of the bottle touches on the rolling spindles horizontally and rotates at a suitable revolution speed. It is placed in an incubator during cell culture.

from Pharmacia Biotech (Uppsala, Sweden). Maxi-Sorp F96 plates came from NUNC (Denmark). All other chemicals made in local chemicals were analytical grade.

DMRB is a right cylinder, as shown in Figure 1. It has two extrusive mouths on the two circular planes, respectively. The volume of the bottle is $50-100 \mathrm{~mL}$ and the diameter is $4-5 \mathrm{~cm}$. During cell cultivation, the two mouths of the bottle were covered with a piece of foil or a lid and the bottle was placed on the rolled-spindles of the cell culture system, by the curved surface. At least ten bottles can be rotated on the spindles simultaneously. The rolling cell culture system generally includes rolling machine with rolled-spindles and a special electric device to control revolution speed. The DMRB was allowed to rotate in the direction either clockwise or anticlockwise. The bottles and rolling machine were installed in the humidi ed incubator containing $5 \% \mathrm{CO}_{2}$ at $37 \mathrm{C}$. The revolution control device was placed outside.

Cell culture. The hybridoma cell line (3E8) was established resulting from fusion of murine P3-X63 Ag 8.653 myeloma cells with mouse Balb/c B-lymphocytes immunized against human chorionic gonadotropin (hCG) as described [18]. The DMEM medium was supplemented with $50 \mu \mathrm{M}$ gentamycin, at $\mathrm{pH} 7.4$ (adjusted with $7.4 \%$ $\mathrm{NaHCO}_{3}$ when necessary). Viable cells were seeded at a density of $1.5-2 \quad 10^{5} / \mathrm{mL}$ for both T- asks $\left(50 \mathrm{~mL}, 25 \mathrm{~cm}^{2}\right.$ containing $10 \mathrm{~mL}$ of medium) and DMRBs (also containing $10 \mathrm{~mL}$ of medium). Cells were allowed to grow in DMEM medium with $1 \%, 5 \%$, and $10 \%$ FCS, respectively. For rotating DMRB culture, the revolution speed was 2 turns/min. Three bottles, at least, were not rotated as static control.

To enhance productivity by increasing the surface area to a given medium volume, the hybridoma cells were cultured in the presence of microcarriers. In the experiment, we used the microcarrier Cytodex 3 according to the manufacturer's instruction. The glassware was siliconized to prevent the microcarriers from sticking. Silicone was dissolved in 5\% chloroform, then the silicochloroform solution was poured into glassware and poured out when the wall was immersed equably. The glassware was dried and autoclaved prior to use. Dry cytodex microcarriers $\left(800 \mathrm{~cm}^{2} / 50 \mathrm{~mL}\right)$ were hydrated with calciumand magnesium-free phosphate-buffered saline $\mathrm{CCa}^{2+}$ and $\mathrm{Mg}^{2+}$-free PBS) in a siliconized spinner ask on a shaker overnight. The microcarriers were washed twice with $\mathrm{Ca}^{2+}$ - and $\mathrm{Mg}^{2+}$-free PBS and then autoclaved for 15 minutes at $115 \mathrm{C}, 15$ psi. Residual $\mathrm{Ca}^{2+}$ - and $\mathrm{Mg}^{2+}$-free PBS was removed and the microcarriers were washed and resuspended in warm media before use. Usually, $100 \mathrm{~mL}$ medium contained $0.3 \mathrm{~g}$ of microcarriers.

Determination of cell growth. Cell concentrations were determined by counting a cell suspension diluted $1: 1$ (v/v) with $0.2 \%$ Trypan blue by a hemacytometer. Visual analysis of the cultures revealed an admixture of live (Trypan-blue negative) and dead (Trypan-blue positive) cells under each experimental condition.

$M A b$ concentrations. Antibody levels in the supernatants of hybridoma cultures were determined by an enzyme-linked immunoassay (ELISA) [19]. Maxi-Sorp F96 plates were coated with hCG $(20 \mu \mathrm{g} / \mathrm{mL}$ in PBS, $100 \mu \mathrm{L} /$ well) and incubated at $4 \mathrm{C}$ overnight, and the wells were blocked with PBS containing 1\% BSA for 2 hours at $37 \mathrm{C}(200 \mu \mathrm{L} /$ well $)$. Then the wells were washed three times with PBS containing $0.5 \%$ Triton X-100 (200 $\mu \mathrm{L} /$ well). The samples, negative control (medium) and positive control (ascites of the mice with hybridomas), were added $(50 \mu \mathrm{L} /$ well $)$ and incubated for 1 hour at $37 \mathrm{C}$. The wells were then washed for three times with PBS containing $0.5 \%$ Triton X-100 and 1\% BSA $(100 \mu \mathrm{L} /$ well $)$, and incubated for 1 hour with alkalinephosphatase-conjugated goat anti-mouse IgG at $37 \mathrm{C}$. They were washed three times with PBS containing $0.5 \%$ Triton X-100 and twice with double distilled water (200 $\mu \mathrm{L} /$ well). Then 3,3,5,5-tetramethylbenzidine (TMB, in $\mathrm{PB}$ buffer, $\mathrm{pH}$ 6.0) chromogen-substrate was added $(100 \mu \mathrm{L} /$ well $)$ and incubated in dark. The chromogenic reaction was stopped after 15-30 minutes with $0.5 \mathrm{M} \mathrm{H}_{2} \mathrm{SO}_{4}$ and the absorbance of each well was detected at $492 \mathrm{~nm}$ in a spectrophotometer (Bio-Rad Model 3550 Microplate Reader JP41).

\section{RESULTS AND DISCUSSIONS}

\section{Hybridoma growing on Cytodex-3 beads}

Microcarrier beads $(0.3 \mathrm{~g} / 100 \mathrm{~mL}$ medium) were added in the media containing FCS $(1 \%, 5 \%$, and $10 \%)$ in both DMRB and T- ask ( Figure 2b). In static culture, cells can perch on the microcarriers and occupy the most surface of the beads (90\%-95\%), growing in a threedimensional manner in DMRB (Figure 2a). For T- ask, however, $40 \%-50 \%$ of hybridoma cells perch and grow on the beads under the same conditions. The higher cellperching ratio onto the microcarriers in DMRB may be resulted from a better ventilation of the two opposite necks, which are helpful to gas exchanging.

Under a rotating condition (2-10 rpm), cell perching ratio on the beads decreases during cells growing in DMRB. The hybridoma cells on the beads are subjected to an increase in shearing force. They are shorn off the beads and resuspended in medium. The faster the revolution, the higher the shearing force and the more cells shorn off 


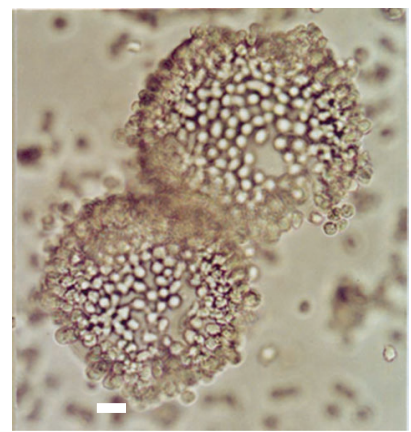

(a)

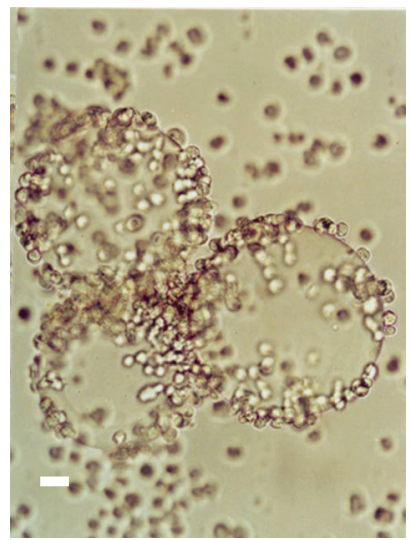

(b)

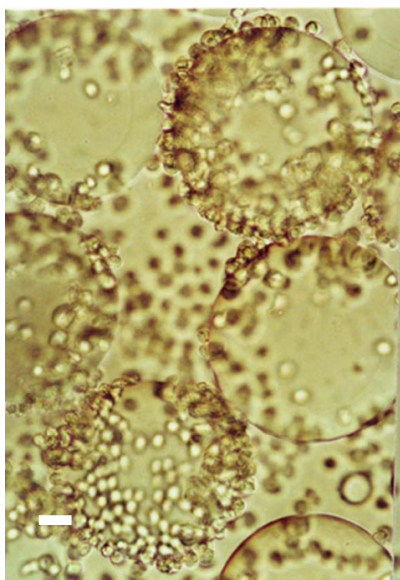

(c)

FIGURE 2. Cell growth status of murine hybridoma cells perching on microcarriers. The DMEM medium was supplemented with $50 \mu \mathrm{M}$ gentamycin, at $\mathrm{pH} 7.4$ (adjusted with $7.4 \% \mathrm{NaHCO}_{3}$ when necessary). Viable cells were seeded at a density of $1.5-2 \quad 10^{5} / \mathrm{mL}$ for both T-asks $\left(50 \mathrm{~mL}, 25 \mathrm{~cm}^{2}\right.$ containing $10 \mathrm{~mL}$ of medium) and DMRBs (containing $10 \mathrm{~mL}$ of medium). Microcarrier beads $(0.3 \mathrm{~g} / 100 \mathrm{~mL}$ medium $)$ were added to the medium and cells were allowed to grow in DMEM medium $\left(5 \% \mathrm{CO}_{2}\right.$, at $\left.37 \mathrm{C}\right)$ with $1 \%$, $5 \%$, and 10\% FCS, respectively. Cells were cultured in static DMRBs supplemented with 10\% FCS for 72 hours. Cells growing in Task were as control (bar $=0.1 \mathrm{~mm}$ ). For rotating DMRB culture (supplemented with $10 \% \mathrm{FCS}$ ), cells were under a revolution speed of 2 turns/min for 72 hours. For each experiment, three bottles, at least, were as a group.

the beads. Only $1 \%-3 \%$ cells can perch on the beads when revolution speed gets to $10 \mathrm{rpm}$. This is to say, the number of cells perching on the beads is directly related to the revolution of DMRB. Therefore, it is important to use a suitable revolution speed to have a low shearing force on cells. On the basis of our experiments, a suitable revolution speed should be about $2 \mathrm{rpm}$, under which cell perching ratio can keep at 40\%-50\% (Figure 2c).

\section{Cell growth in double-mouthed rotating bottles}

Figure 3 shows total (left) and viable (right) numbers of hybridoma cells cultured in both DMRBs and T- asks.

The maximum densities of cells cultured in rotating DMRBs are observably higher than those in T-asks, in all the media containing $1 \%, 5 \%$, and $10 \%$ FCS. The total number of cells reaches approximately $1.5 \quad 10^{6} / \mathrm{mL}$ around 72 hours while cells are cultured in the medium containing 10\% FCS in rotating DMRBs. However, it is approximately $1.0 \quad 10^{6} / \mathrm{mL}$ while cells are cultured in Tasks. Similar results have been obtained as the viable cells were identi ed. Experiments also show that cells densities in rotating DMRBs are higher than those in static DMRBs (data not shown), suggesting that the clinonational rotation plays an important role in a rotating DMRB culture.

\section{MAb production in double-mouth roller bottles}

Aliquots were daily taken from the culturing media to measure the MAb concentration during the culture. Changes in MAb concentrations in the medium supplemented with 5\% FCS are shown in Figure 4. As indicated, both accumulated (a) and daily (b) MAb production of cells cultured in rotating DMRBs are distinguish- ably higher than those of cells cultured in T-asks. Interestingly, for DMRBs, the highest production rate is achieved on the rst day. The rst three-day MAb production accounts for over $95 \%$ of the total yield during the ve-day culture. It suggests that the antibody should be harvested in 72 hours, to have a high yield of antibody, saving time and materials. Statistically, the nal production of a rotating DMRB is approximately $42.5 \%$ higher than that of a T-ask. This result indicates that rotation plays a signi cant role, not only in cell growth, but also in MAb production.

\section{Comparison of cell growth and MAb production in $D M R B$ and in T-ask}

Cell growth and MAb production in DMRB groups and T-ask groups within 72 hours are shown in Table 1. Increase in production rate of MAb is highly correlated with the viable cell number. It indicates that the increasing MAb production is largely resulted from an increase of the viable cell number. In other words, the synthesis rate of MAb increased proportionally to the cell number. A further possibility for enhancing MAb productivity is considered with the increase in the surface area by the microcarriers on which cells grow and perch. Consequently, the cell density per culture volume may be improved by means of the microcarriers [20,21]. For our experiments, Cytodex 3 is used as the microcarriers, which are macroporous matrix based on polyethylene and weighted by silica. These microcarriers, alkali and acid resistant, are steamily sterilizable at $121 \mathrm{C}$ ( 1 bar) and are not swollen up on hydration. Cytoline-3 microcarriers provide both an external surface and an interior space with pore size between 10 

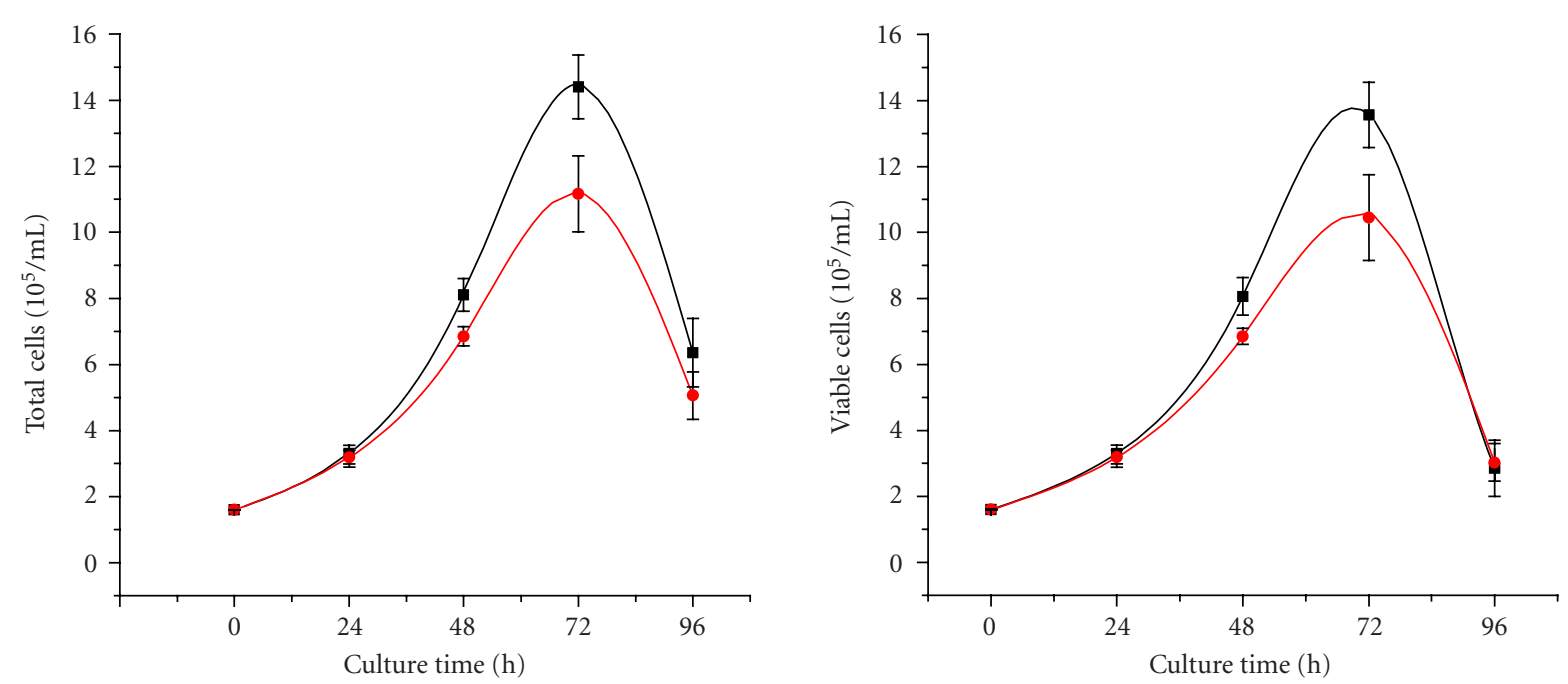

(a)
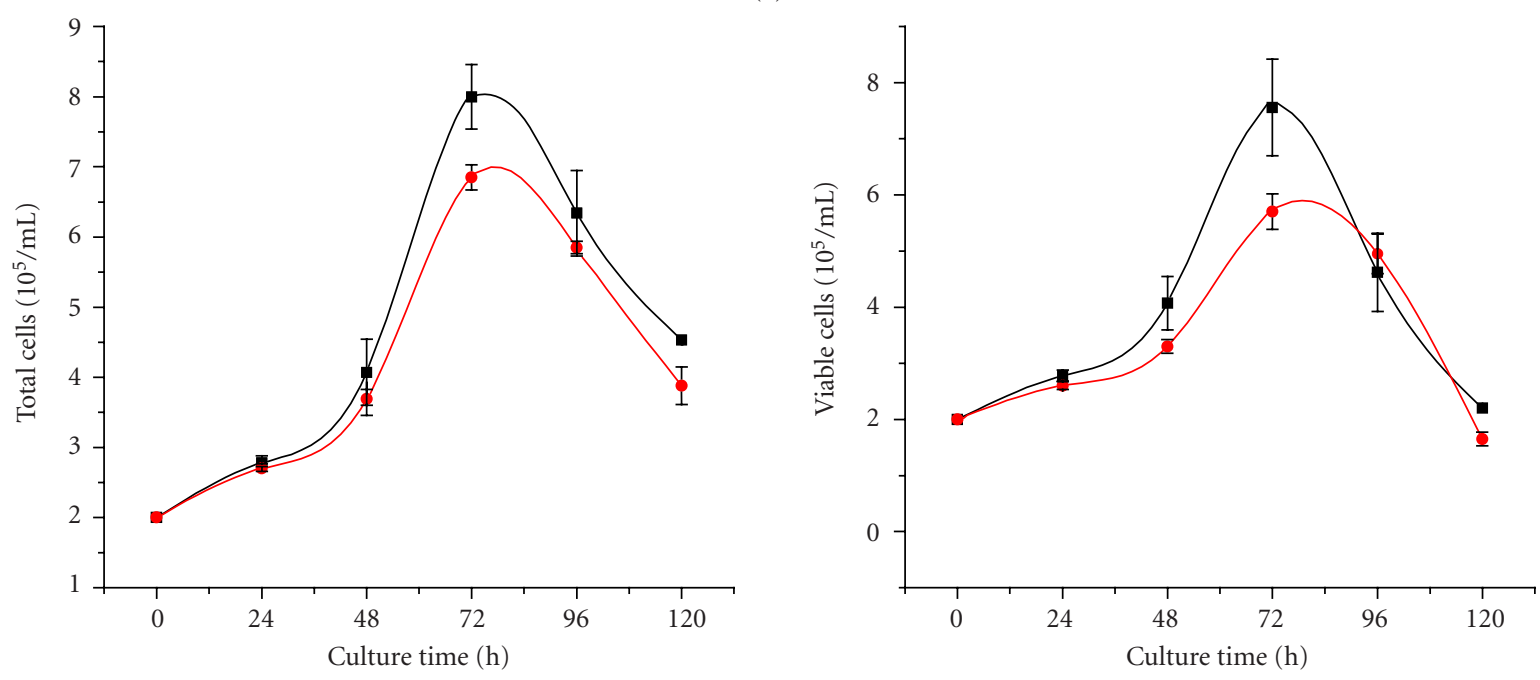

(b)
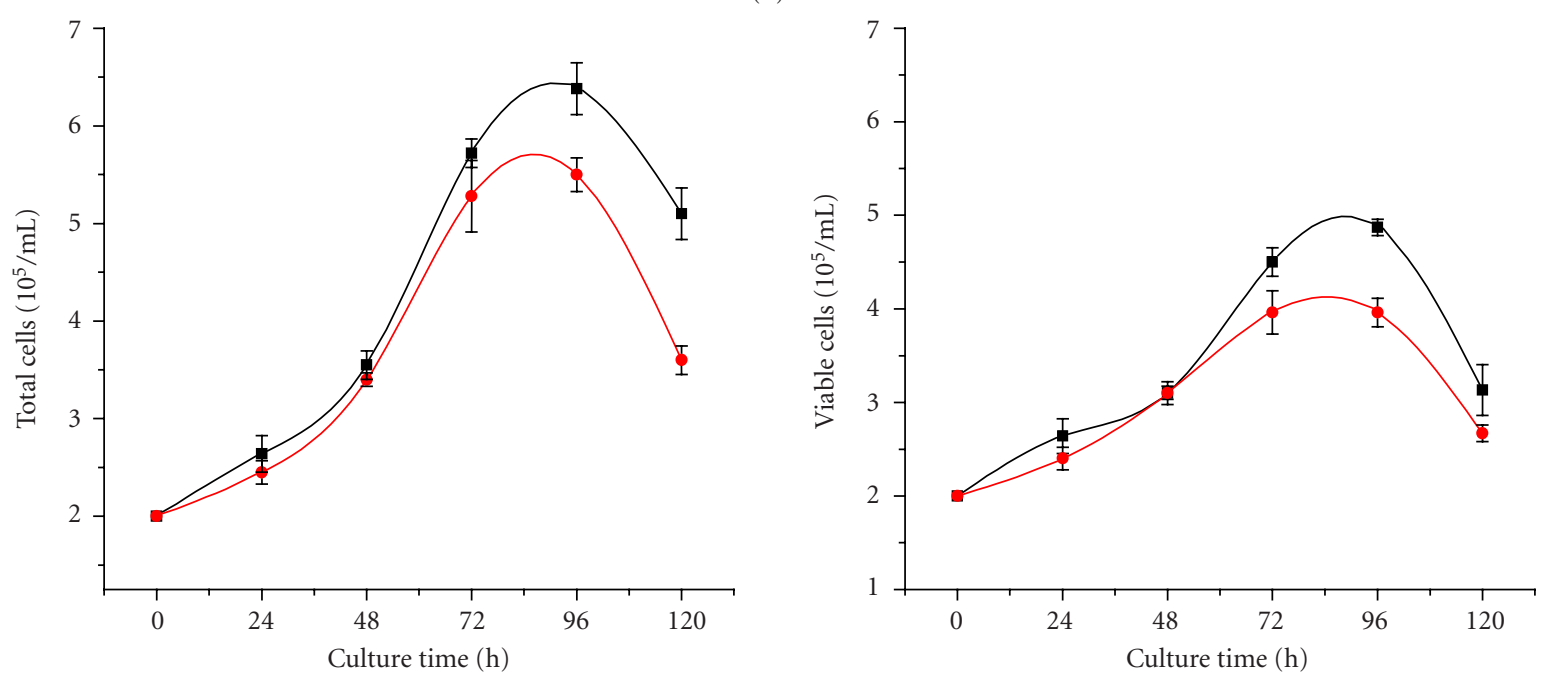

(c)

Figure 3. Comparison of cell growth in DMRBs and T- asks. Total (left) and viable (right) numbers of hybridoma cells cultured in both DMRBs and T- asks in medium containing 10\% (a), 5\% (b), and 1\% (c) FCS, respectively. The black curve represents cell number in DMRBs and the red curve represents cell number in T- asks. Each point is the mean of three independent parallel cultures. Vertical bars are SDs. 


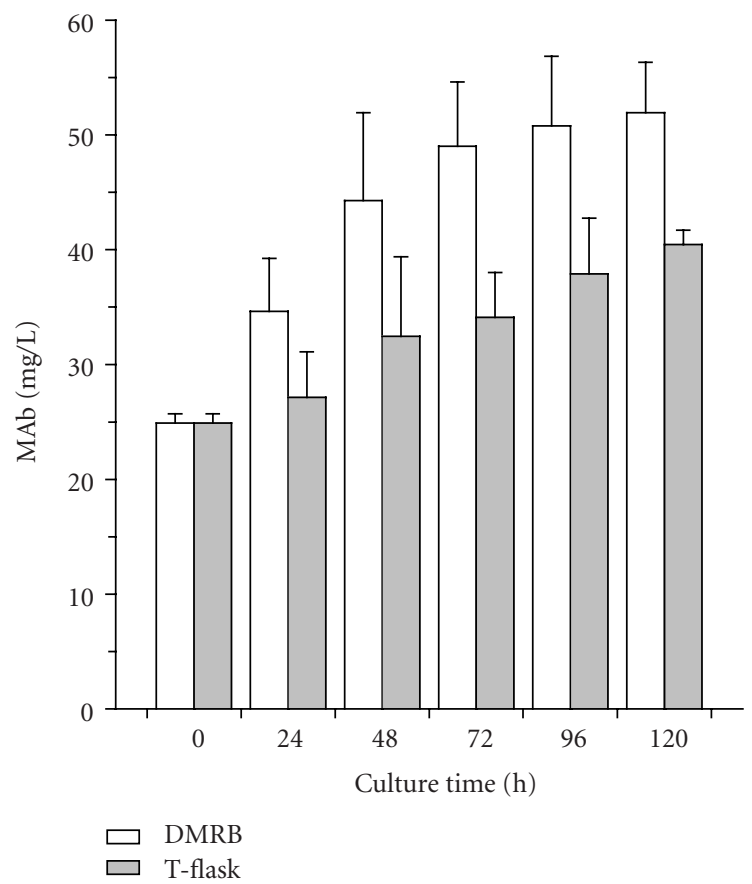

(a)

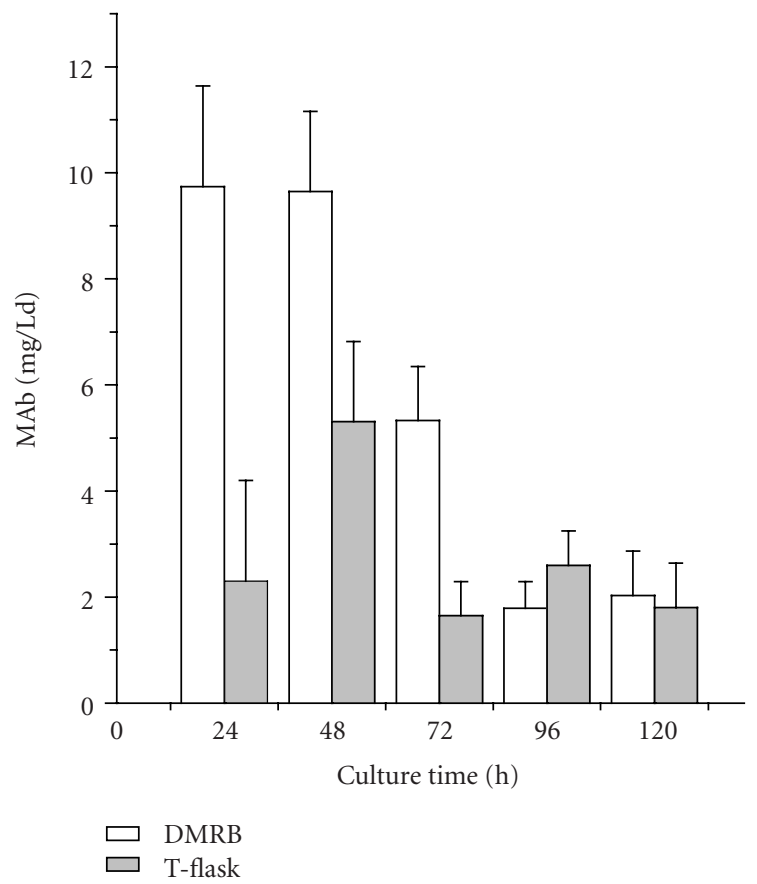

(b)

FIGURE 4. Comparison of MAb production rates between rolling DMRBs and T- asks. The MAb concentrations are measured in the medium supplemented with 5\% FCS in both DMRBs and T- asks. (a) Accumulated MAb production. (b) Daily MAb production. The values are mean SD of three independent experiments. Vertical bars are SDs.

TABLE 1. MAb productivity and growth of the resultant cells cultured for 72 hours.

\begin{tabular}{|c|c|c|c|c|c|c|c|}
\hline Group & $\begin{array}{c}\text { FCS } \\
\text { concentration }\end{array}$ & $\begin{array}{l}\text { Total cells } \\
\left(10^{5} / \mathrm{mL}\right)\end{array}$ & $\begin{array}{l}\text { Increase } \\
\text { rate }(\%)\end{array}$ & $\begin{array}{l}\text { Viable cells } \\
\left(10^{5} / \mathrm{mL}\right)\end{array}$ & $\begin{array}{l}\text { Increase } \\
\text { rate }(\%)\end{array}$ & $\begin{array}{c}\text { MAb } \\
(\mu \mathrm{g} / \mathrm{mL})\end{array}$ & $\begin{array}{l}\text { Increase } \\
\text { rate }(\%)\end{array}$ \\
\hline T- ask & $10 \% \mathrm{FCS}$ & $11.77 \quad 1.43$ & 100 & $11 \quad 1.46$ & 100 & $37.2 \quad 3.57$ & 100 \\
\hline DMRB & & $13.75 \quad 0.88$ & 116.82 & $13.27 \quad 1.5$ & 120.6 & $45.3 \quad 4.4$ & 121.8 \\
\hline T- ask & $50 \% \mathrm{FCS}$ & $6.27 \quad 0.42$ & 100 & $5.64 \quad 0.26$ & 100 & $34.8 \quad 4.1$ & 100 \\
\hline DMRB & $5 \%$ геS & $7.94 \quad 1.38$ & 126.63 & $\begin{array}{ll}7.9 & 1.27\end{array}$ & 141.07 & $49.5 \quad 5.6$ & 142.49 \\
\hline T- ask & $1 \%$ & $5.1 \quad 0.24$ & 100 & $3.8 \quad 0.36$ & 100 & $35.41 \quad 7.3$ & 100 \\
\hline DMRB & $1 \%$ FCS & $5.9 \quad 0.32$ & 115.69 & $\begin{array}{ll}4.8 & 0.37\end{array}$ & 126.3 & $44.45 \quad 5.78$ & 125.53 \\
\hline
\end{tabular}

The values are mean $\mathrm{SD}$ from three independent experiments. Comparison of DMRB groups with T- ask group; $\quad P<.1, \quad P<.05$.

and $400 \mu \mathrm{M}$, which can be populated also by cells grown in suspension and used in stirred cultures. However, cells inhabiting inside the pores could not be observed during the culture.

Cell growth density, MAb production, and reasonable cost are important criteria to evaluate alternative methods to conventional T- ask. The method using DMRB to culture hybridoma cells has some signi cant advantages: (1) to produce higher MAb at a low cost, (2) easily to handle in lab, (3) conveniently to process and investigate the optimal conditions for different MAb, and (4) readily to produce a larger-scale MAb when necessary. Furthermore, the method makes it possible to produce MAb as a putative process on an industrial scale, and to have obvious advantages, such as a high yield and a low cost.

\section{ACKNOWLEDGMENTS}

We are grateful to Dr Man-Tong Mei for supporting our experiments. This project is jointly supported by the Foundation of Chinese 863-Plan (863-2-7-2-16), the Key Foundation of Chinese Academy of Sciences (KSCX2SW214-1), and the National Natural Foundation (no 39610710141). 


\section{REFERENCES}

[1] Köhler G, Milstein C. Continuous cultures of fused cells secreting antibody of prede ned speci city. $\mathrm{Na}$ ture. 1975;256:495-497.

[2] Voigt A, Zintl F. Hybridoma cell growth and antineuroblastoma monoclonal antibody production in spinner asks using a protein-free medium with microcarriers. J Biotechnol. 1999;68(2-3):213-226.

[3] Boyd JE, James K. Human monoclonal antibodies: their potential, problems, and prospects. In: Mizrahi A, ed. Monoclonal Antibodies: Production and Application. New York, NY: Alan R. Liss Inc; 1989:1-43.

[4] Falkenberg FW, Weichert H, Krane M, et al. In vitro production of monoclonal antibodies in high concentration in a new and easy to handle modular minifermenter. J Immunol Methods. 1995;179(1):1329.

[5] Sjörgren-Jansson E, Jeanson S. Growing hybridomas in dialysis tubing, optimization of technique. In: Zola E, ed. Laboratory Methods in Immunology. Boca Raton, Fla: CRC Press; 1990:1-41.

[6] Lipman NS, Jackson LR. Hollow bre bioreactors: an alternative to murine ascites for small scale $(<1$ gram) monoclonal antibody production. Res Immunol. 1998;149(6):571-576.

[7] Falkenberg FW. Monoclonal antibody production: problems and solutions. Res Immunol. 1998;149(6): 542-547.

[8] Schwarz RP, City L, Wolf DA, Trinh TT. Horizotally rotated cell culture system with a coaxial tubular oxygenator. US patent 5026 650. June 25, 1991.

[9] Larsen P. Geotropism an introduction. In: Ruhland W, ed. Encyclopedia of Plant Physiology. Berlin: Springer-Verlag; 1962:34-73.

[10] Cogoli A, Tschopp A, Fuchs-Bislin P. Cell sensitivity to gravity. Science. 1984;225(4658):228-230.

[11] Gruener R. Stimulated hypogravity and synaptogenesis in culture. Physiologist. 1985;28:79-80.

[12] Rulong S, Takagishi Y, Koga K, et al. Clinostat rotation promotes HGF/SF-induced morphogenesis of rat pancreatic oval cells. Jpn J Aerosp Environ Med. 1998;35:55-61.

[13] Kunisada T, Kawai A, Inoue H, Namba M. Effects of simulated microgravity on human osteoblast-like cells in culture. Acta Med Okayama. 1997;51(3):135140.

[14] Moore D, Cogoli A. Gravitational and space biology at the cellular level. In: Moore D, Bie P, Oser H, eds. Biological and Medical Research in Space. 4th ed. Berlin: Springer Verlag; 1996:1-106.

[15] Zhau HE, Goodwin TJ, Chang SM, Baker TL, Chung LW. Establishment of a three-dimensional human prostate organoid coculture under microgravitysimulated conditions: evaluation of androgeninduced growth and PSA expression. Vitro Cell Dev Biol Anim. 1997;33(5):375-380.
[16] He RQ, Zhang JZ, Wang Y, Jiao HL. Doublemouthed rolling bottle for cell and tissue cultures. Chinese patent ZL 002 45773. 3. 2000.

[17] He RQ, Zhang JZ, Wang Y, et al. Rolling culture system for cell and tissue techniques. Chinese patent. ZL 002 52933. 5. 2000.

[18] Leblond L, Lemieux E, Patel P, Crine P. Screening of monoclonal antibodies for hCG for affinity and speci city. Biochem Cell Biol. 1988;66(8):910-916.

[19] Caponi L, Migiorini P. Antibody usage in the lab. In: Springer Lab Manual. Berlin: Springer-Verlag; 1999:19-23.

[20] Hirtenstein M, Clark J, Lindgren G, Vretblad P. Microcarriers for animal cell culture: a brief review of theory and practice. Dev Biol Stand. 1980;46:109116.

[21] Schurch U, Cryz SJ Jr, Lang AB. Scale-up and optimization of culture conditions of a human heterohybridoma producing serotype-speci c antibodies to pseudomonas aeruginosa. Appl Microbiol Biotechnol. 1992;37(4):446-450.

Corresponding author.

E-mail: herq@sun5.ibp.ac.cn

Fax: +8610 64853625; Tel: +861064889876 

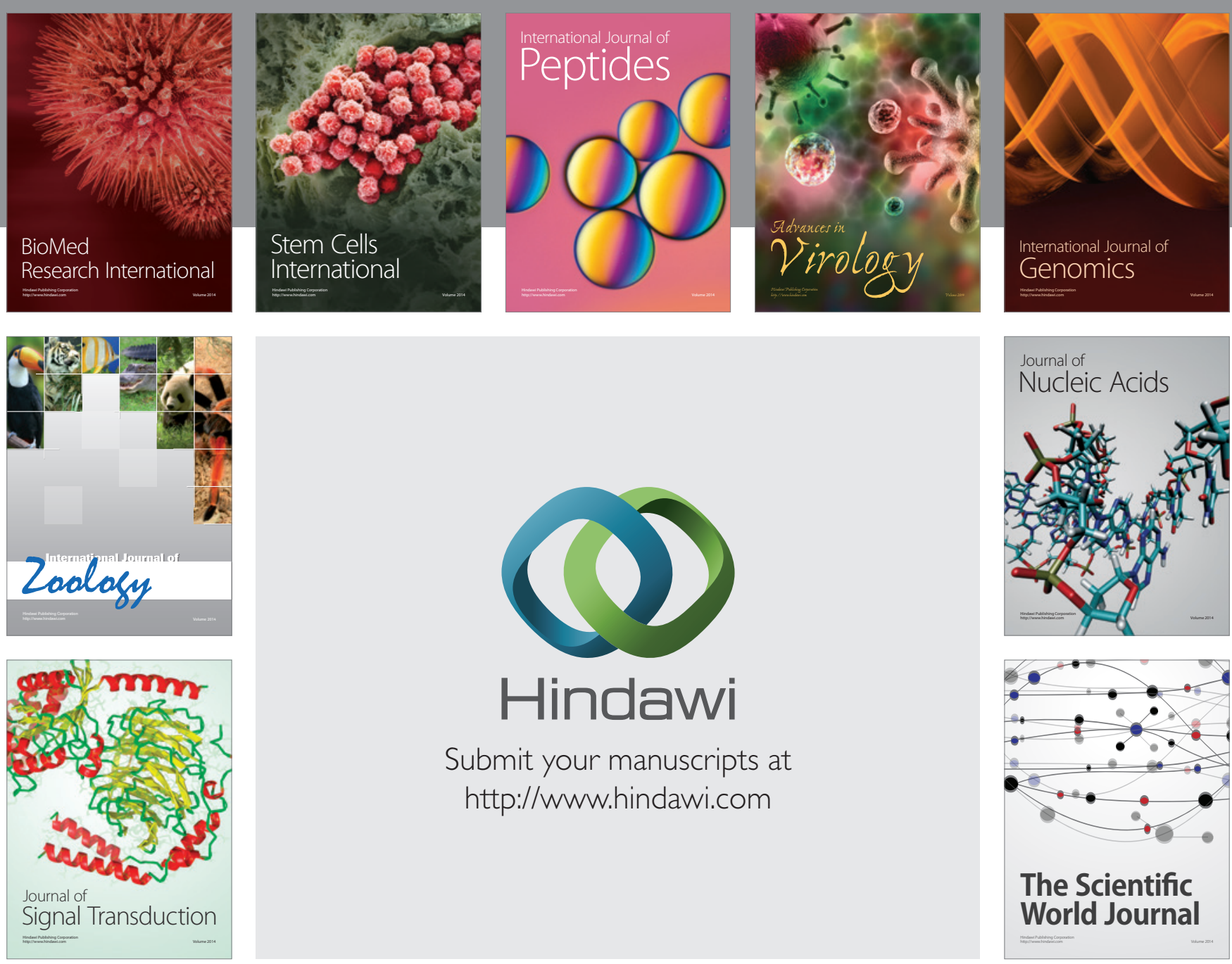

Submit your manuscripts at

http://www.hindawi.com
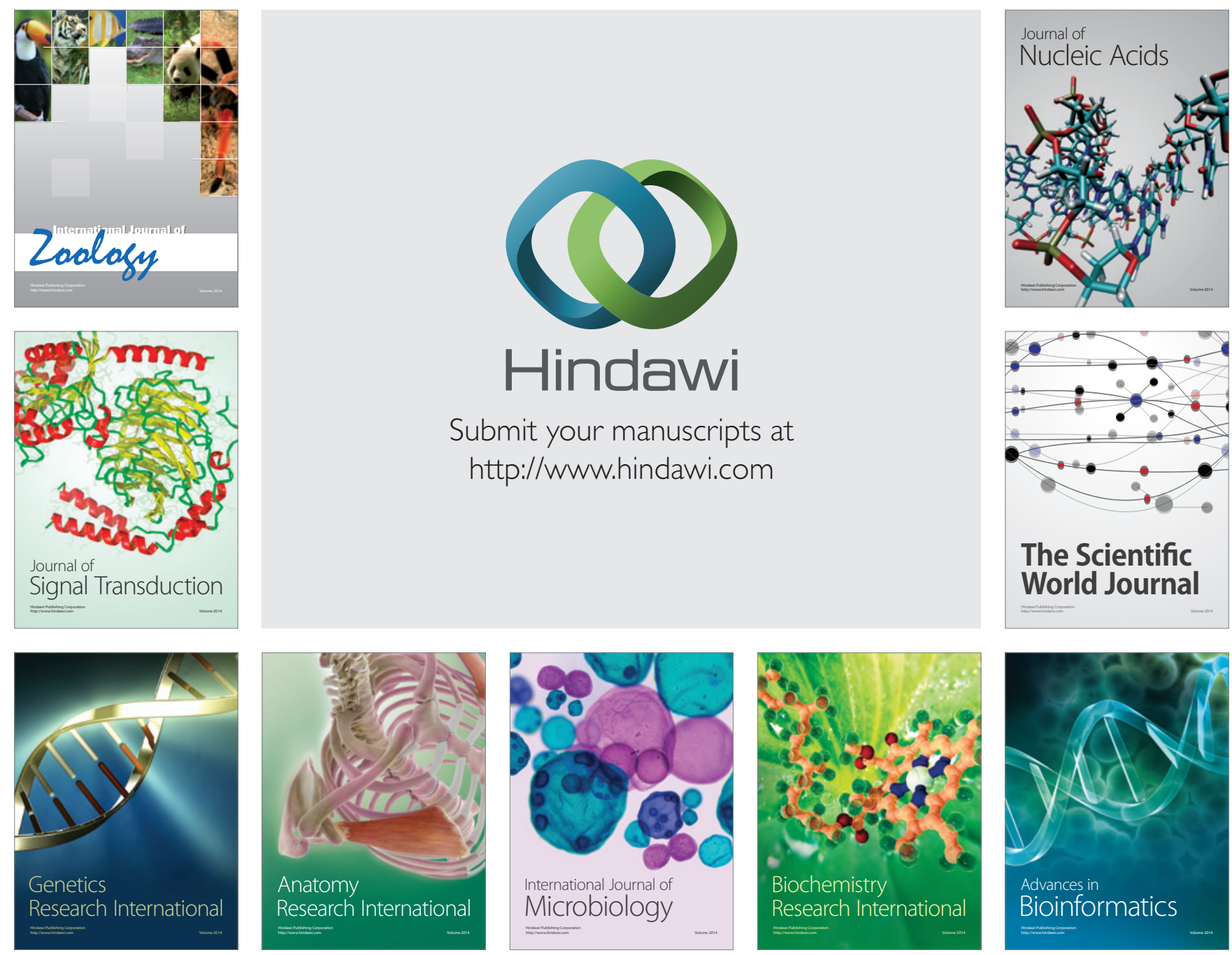

The Scientific World Journal
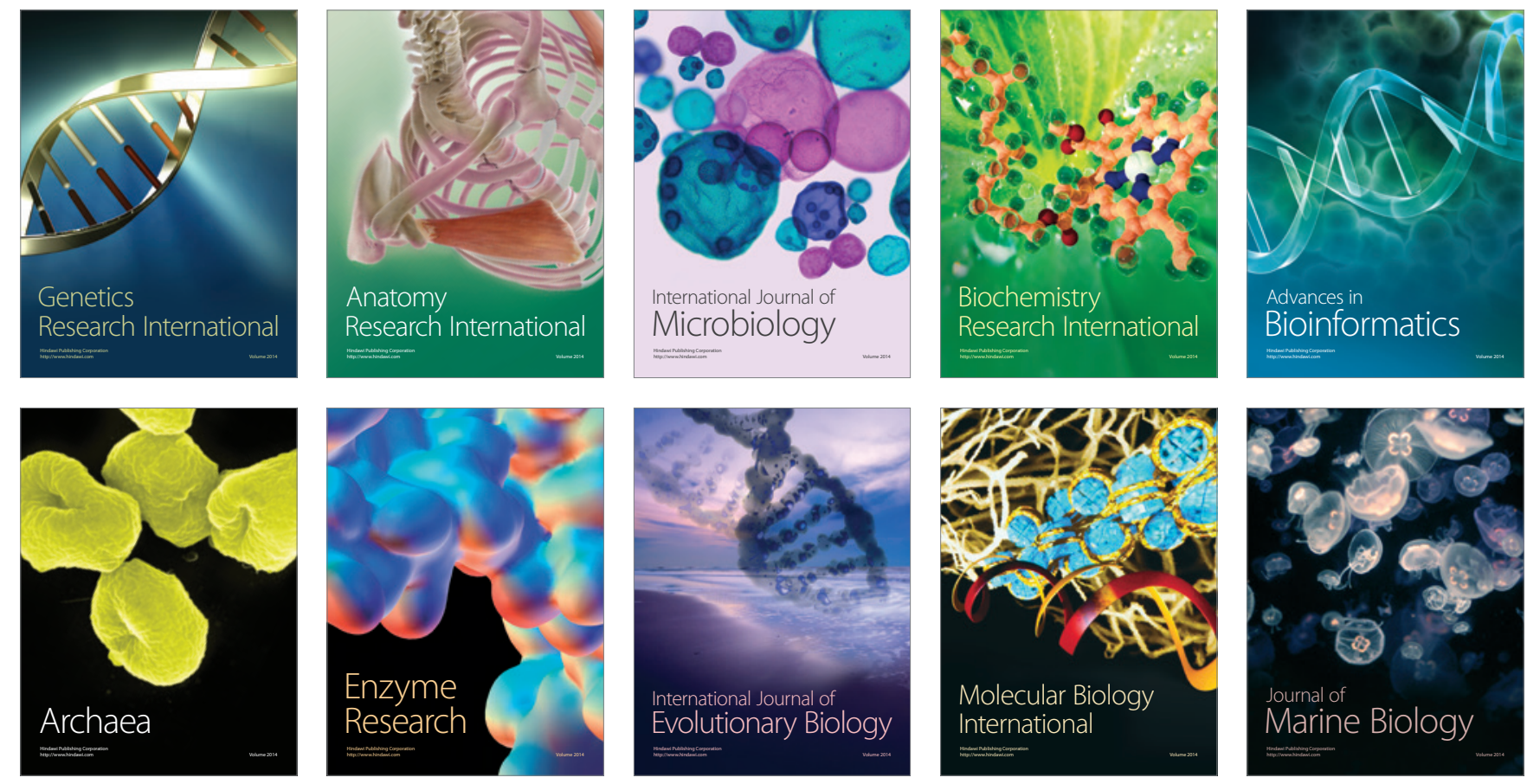